\title{
Unilateral Cranial Polyneuropathy in Herpes Zoster Oticus: Infection teaching us Anatomy
}

\author{
Abdul Qavi $D M^{1}$, Ashutosh Tiwari $D M^{2}$, Pradeep Kumar Maurya $D M^{\mathfrak{3}}$, Ajai Kumar Singh $D M^{4}$, \\ Pradeep Kumar $M D^{5}$ \\ 1,2,3,4,5 Department of Neurology, Dr. Ram Manohar Lohia Institute of Medical Sciences, Lucknow, Uttar Pradesh, India \\ Date of submission: $29^{\text {th }}$ May 2020 \\ Date of acceptance: $16^{\text {th }}$ November 2020 \\ Date of publication: $1^{\text {st }}$ December 2020
}

\begin{abstract}
Herpes zoster oticus or Ramsay Hunt syndrome is an uncommon neurological manifestation of herpes virus infection causing external ear rash with otalgia and facial nerve palsy. Rarely herpetic infection may present with multiple cranial nerves palsies involving VII, VIII, IX and X cranial nerves.

Here we report a case of herpes zoster oticus with multiple cranial nerve palsy. This case study will help in understanding the dermatomal distribution of cranial nerves with cranial polyneuropathy due to reactivation of neurotropic herpes virus.

Some interesting case reports regarding different cranial nerve involvement in herpetic infection are discussed in the table which helps in understanding the neurotropism of herpes virus.
\end{abstract}

Key words: Cranial Polyneuropathy, Ear rashes, Facial palsy, Herpes Zoster oticus

\section{Introduction}

$\mathrm{H}$ erpes zoster oticus or Ramsay Hunt syndrome is an uncommon neurological manifestation of herpes virus infection causing external ear rash with otalgia and facial nerve palsy. ${ }^{1}$ Sometimes this herpetic infection may

Access this article online
Website: https://www.nepjol.info/index.php/NJN
DOI: https://doi.org/10.3126/njn.v17i3.33129
HOW TO CITE
Qavi A, Tiwari A, Maurya PK, Singh AK, Kumar P. Unilateral
Cranial Polyneuropathy in Herpes Zoster Oticus: Infection
teaching us Anatomy. NJNS. 2020;17(3):59-62

${ }^{1}$ ORCID id: 0000-0002-4223-5540

${ }^{2}$ ORCID id: 0000-0002-2311-8891

${ }^{3}$ ORCID id: 0000-0002-6485-7527

${ }^{4}$ ORCID id: 0000-0001-9551-4378

${ }^{5}$ ORCID id: 0000-0001-6407-703X

Address for correspondence:

Dr. Abdul Qavi,

Assistant Professor, Department of Neurology,

Dr. Ram Manohar Lohia Institute of Medical Sciences,

Lucknow, Uttar Pradesh, India

E-mail: drqavi2008@gmail.com

Phone: +919450417111

Copyright (C 2020 Nepalese Society of Neurosurgeons (NESON)

ISSN: 1813-1948 (Print), 1813-1956 (Online) present with multiple cranial nerves palsies involving VII, VIII, IX and X cranial nerves. ${ }^{2}$

\section{Case report}

A 55 years old man presented to us with right ear pain, deviation of angle of mouth to left side and unsteadiness while walking. First, he developed ear pain and on the next day he noticed rashes around right ear involving pinna. On the same day he developed a nasal twang of voice with nasal regurgitation. He was complaining of tinnitus in right ear with difficulty in walking and swaying on the third day of illness. On examination there was lower motor neuron palsy of right cranial nerve VII with facial deviation to the left side and involvement of right sided cranial nerve VIII including both vestibular and cochlear divisions. Gag reflex on the right side was absent with drooped soft palate depicting right sided cranial nerves IX and $\mathrm{X}$ palsies. Local examination revealed herpetic rashes and crust on the right pinna, external ear canal and on right sided soft palate (Figure 1).

There was no neck rigidity and signs of meningeal irritation were absent. On higher mental function examination, the patient was conscious and oriented to time place and persons, alert and following commands with intact memory. Cerebellar examination was normal but the patient had vestibular ataxia. The clinical features of meningitis and/ or encephalitis were absent.

Patient was admitted and Ryle's tube was inserted for feeding and oral medications. In routine blood investigation he was found to be recently diagnosed 


\section{Qavi et al}

diabetes mellitus. His CSF examination was showing lymphocytic pleocytosis (WBC count was 45 cells $/ \mathrm{mm}^{3}$, polymorphs $10 \%$, lymphocytes $90 \%$ ) with slightly raised proteins $(95.0 \mathrm{mg} / \mathrm{dl})$ and normal sugar level $(82 \mathrm{mg} / \mathrm{dl}$ with corresponding blood sugar was $156 \mathrm{mg} / \mathrm{dl})$. CSF was clear watery in appearance and ADA level was 1.1. CSF PCR for Herpes Simplex Virus and Varicella Zoster virus were negative. MRI brain with contrast was also normal without any evidence of meningeal enhancement or parenchymal intensity changes. The abnormality in the CSF examination can be explained by immunological reaction to reactivation of latent herpes virus infection presenting in the form of Herpes zoster oticus. Patient was treated with antiviral oral valacyclovir $1 \mathrm{gm}$ three times a day for seven days, acyclovir ointment for local application, prednisolone $1 \mathrm{mg} / \mathrm{kg}$ with tapering and oral hypoglycemic agents monitoring sugar levels and physiotherapy. The patient improved symptomatically allowing removal of Ryle's tube and reduction in pain, rashes and gait difficulty in two weeks of treatment. However residual facial palsy was present on the last follow up (three months after discharge).

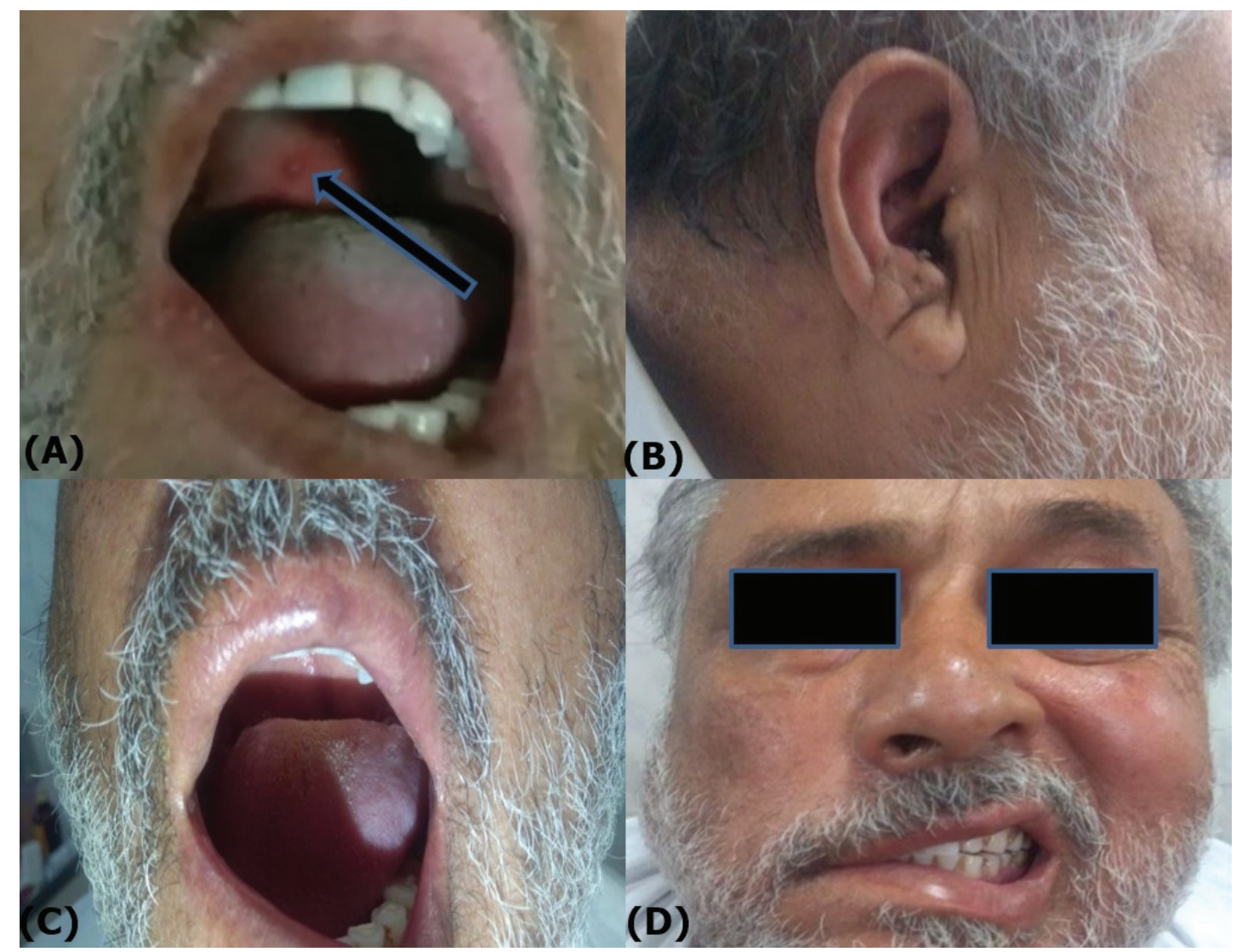

Figure 1. (A) Rashes on right palate, (B) Resolving rashes and crusting over pinna and neck, (C) Right palatal palsy, on attempt to phonation flat and drooped right soft palate with median raphe deviated to left, (D) Right sided LMN facial palsy 
Unilateral Cranial Polyneuropathy in Herpes Zoster Oticus

\begin{tabular}{|c|c|c|c|c|c|c|c|}
\hline S.N. & Author & $\begin{array}{l}\text { Age/ } \\
\text { Sex }\end{array}$ & $\begin{array}{l}\text { Risk Factors/ } \\
\text { Co-morbidity }\end{array}$ & Clinical Features & $\begin{array}{c}\text { Cranial } \\
\text { Nerve } \\
\text { Involved }\end{array}$ & $\begin{array}{l}\text { Treatment } \\
\text { given }\end{array}$ & $\overline{\text { Remarks }}$ \\
\hline 1 & $\begin{array}{l}\text { Sato K. et al. } \\
1991\end{array}$ & $\begin{array}{l}56 y / \\
\text { female }\end{array}$ & none & $\begin{array}{l}\text { Right ear and facial } \\
\text { pain, respiratory } \\
\text { distress, fatigue }\end{array}$ & $\begin{array}{l}\text { V, VII, VIII, } \\
\text { IX, X, XI and } \\
\text { XII }\end{array}$ & $\begin{array}{l}\text { Ventilatory } \\
\text { support, } \\
\text { Antiviral, } \\
\text { steroid }\end{array}$ & $\begin{array}{l}\text { Improved } \\
\text { with late } \\
\text { recovery of } \\
\text { hoarseness of } \\
\text { voice }\end{array}$ \\
\hline 2 & $\begin{array}{l}\text { Kikuchi H. et } \\
\text { al } 1995\end{array}$ & $\begin{array}{l}50 \mathrm{y} / \\
\text { male }\end{array}$ & none & $\begin{array}{l}\text { Left sided tinnitus, } \\
\text { hoarseness, dysphagia, } \\
\text { facial deviation }\end{array}$ & $\begin{array}{l}\text { Left VII, IX, } \\
X, X I \text { and } \\
\text { right VII, IX,X }\end{array}$ & $\begin{array}{l}\text { Antiviral, } \\
\text { steroid }\end{array}$ & Improved \\
\hline 3 & $\begin{array}{l}\text { Xanthopoulos } \\
\text { J. et al.2002 }\end{array}$ & $\begin{array}{l}63 y / \\
\text { female }\end{array}$ & Old age & $\begin{array}{l}\text { features of multiple } \\
\text { cranial nerve palsy }\end{array}$ & $\begin{array}{l}\text { V, VII, VIII, } \\
\text { IX, and XII }\end{array}$ & $\begin{array}{l}\text { Acyclovir, } \\
\text { steroid }\end{array}$ & improved \\
\hline 4 & $\begin{array}{l}\text { Sugita- } \\
\text { Kitajima A et } \\
\text { al. } 2009\end{array}$ & $\begin{array}{l}58 y / \\
\text { female }\end{array}$ & $\begin{array}{l}\text { Rheumatic } \\
\text { heart disease }\end{array}$ & $\begin{array}{l}\text { Right ear ache, vertigo, } \\
\text { swallowing difficulty, } \\
\text { hoarse voice }\end{array}$ & $\begin{array}{l}\text { VII, VIII, IX } \\
\text { and X }\end{array}$ & $\begin{array}{l}\text { Antiviral, } \\
\text { steroid }\end{array}$ & $\begin{array}{l}\text { Improved } \\
\text { with late } \\
\text { recovery of } \\
\text { hoarseness of } \\
\text { voice }\end{array}$ \\
\hline 5 & $\begin{array}{l}\text { Lauridsen AG } \\
\text { et al. } 2010\end{array}$ & $\begin{array}{l}56 y / \\
\text { male }\end{array}$ & none & $\begin{array}{l}\text { Ear rashes, features of } \\
\text { multiple cranial nerve } \\
\text { palsy }\end{array}$ & $\begin{array}{l}\text { V, VII, VIII, } \\
\text { IX, X and XII }\end{array}$ & $\begin{array}{l}\text { Antiviral, } \\
\text { steroid }\end{array}$ & Not available \\
\hline 6 & $\begin{array}{l}\text { Sun W et al. } \\
2011\end{array}$ & - & $\begin{array}{l}\text { Diabetes } \\
\text { Mellitus }\end{array}$ & $\begin{array}{l}\text { features of multiple } \\
\text { cranial nerve palsy }\end{array}$ & $\begin{array}{l}\text { V, VII, VIII, } \\
\text { and XII }\end{array}$ & $\begin{array}{l}\text { Insulin, } \\
\text { antiviral, } \\
\text { steroid }\end{array}$ & Improved \\
\hline 7 & $\begin{array}{l}\text { Kim CH. et al } \\
2012\end{array}$ & $\begin{array}{l}66 y / \\
\text { female }\end{array}$ & none & $\begin{array}{l}\text { Left ear pain and } \\
\text { rashes, diplopia, } \\
\text { vertigo, facial palsy }\end{array}$ & VI, VII, VIII & $\begin{array}{l}\text { Acyclovir, } \\
\text { steroid }\end{array}$ & improved \\
\hline 8 & $\begin{array}{l}\text { Coleman C et } \\
\text { al } 2012\end{array}$ & $\begin{array}{l}80 \mathrm{y} / \\
\text { female }\end{array}$ & & $\begin{array}{l}\text { Left sided ear and } \\
\text { facial pain, ear rashes, } \\
\text { tinnitus, left SNHL, } \\
\text { facial deviation }\end{array}$ & $\begin{array}{l}\text { V, VII, VIII, X } \\
\text { and XII }\end{array}$ & $\begin{array}{l}\text { Valacyclovir, } \\
\text { steroid }\end{array}$ & improved \\
\hline 9 & $\begin{array}{l}\text { Patil V. et al. } \\
2014\end{array}$ & $\begin{array}{l}70 \mathrm{y} / \\
\text { male }\end{array}$ & Old age & $\begin{array}{l}\text { Ear rash, headache, } \\
\text { facial deviation, } \\
\text { hiccups, swallowing } \\
\text { difficulty }\end{array}$ & $\begin{array}{l}\text { VII, VIII, IX } \\
\text { and } \mathrm{X}\end{array}$ & $\begin{array}{l}\text { Valacyclovir, } \\
\text { steroid }\end{array}$ & improved \\
\hline 10 & $\begin{array}{l}\text { Talukdar J. et } \\
\text { al. } 2016\end{array}$ & $\begin{array}{l}66 y / \\
\text { male }\end{array}$ & hypothyroidism & $\begin{array}{l}\text { Ear ache and rashes, } \\
\text { swallowing difficulty, } \\
\text { change in voice, } \\
\text { giddiness }\end{array}$ & $\begin{array}{l}\text { VII, VIII, IX } \\
\text { and } \mathrm{X}\end{array}$ & $\begin{array}{l}\text { Valacyclovir, } \\
\text { steroid }\end{array}$ & $\begin{array}{l}\text { Improved } \\
\text { with residual } \\
\text { facial } \\
\text { weakness }\end{array}$ \\
\hline 11 & $\begin{array}{l}\text { Arya D. et al. } \\
2018\end{array}$ & $\begin{array}{l}29 y / \\
\text { male }\end{array}$ & $\begin{array}{l}\text { Retroviral } \\
\text { positive }\end{array}$ & $\begin{array}{l}\text { Headache, facial } \\
\text { deviation, gait } \\
\text { disturbance, abnormal } \\
\text { tongue sensation }\end{array}$ & $\begin{array}{l}\text { V, VII, VIII, } \\
\text { IX, X }\end{array}$ & $\begin{array}{l}\text { Valacyclovir, } \\
\text { steroid } \\
\text { along with } \\
\text { continuation } \\
\text { of } \\
\text { antiretroviral } \\
\text { therapy }\end{array}$ & $\begin{array}{l}\text { Symptomatic } \\
\text { improvement }\end{array}$ \\
\hline
\end{tabular}

Table 1: Review of some interesting cases of Cranial Polyneuropathy in Herpes Zoster Oticus 


\section{Discussion}

Herpes is a neurotropic virus having the ability to remain dormant in dorsal root and cranial nerve ganglia. The reactivation can cause zoster in a dermatomal distribution usually in elderly, diabetes mellitus and immuno-compromised patients. ${ }^{3}$ Sometime due to atypical presentation or involvement of multiple cranial nerves, misdiagnosis occurs. In our case, cranial nerves having fibers of Nucleus Tractus Solitarius, namely VII, IX and $\mathrm{X}$ were involved. Small carotid artery branch supplying contiguous cranial nerves, peripheral anastomosis of $\mathrm{V}$, VII, IX and $\mathrm{X}$ cranial nerves and cranial nerves neighborhood in cavernous sinus has been considered as the plausible explanations for such presentations. ${ }^{2,4}$

After the Bell's palsy, Ramsay Hunt Syndrome is described in literature as second most common cause of unilateral lower motor neuron type of facial nerve palsy with incidence of $12 \% .{ }^{5}$ Rarely this Ramsay Hunt Syndrome can present with cranial polyneuropathy involving V, VII, IX and X cranial nerves as shown in some of interesting case reports in Table 1. 1,2,6

Sharing such cases help us identify simple infections with complex anatomical presentations and simultaneously provide an insight of anatomy and interconnections of cranial nerves.

\section{Conclusion}

Herpes zoster oticus is one of the common causes of unilateral facial palsy and should always be kept as a differential diagnosis of unilateral cranial polyneuropathy especially in elderly patients and associated with comorbidities. Early and prompt management with antiviral and steroid results a favorable outcome.

\section{Conflicts of interest: None \\ Source(s) of support: None}

\section{References}

1. Sweeney CJ, Gilden DH. Ramsay Hunt syndrome. J Neurol Neurosurg Psychiatry. 2001;71: 149-54. https://doi.org/10.1136/jnnp.71.2.149

2. Xanthopoulos J, Noussios G, Papaioannides D, Exarchakos G, Assimakopoulos D. Ramsay Hunt syndrome presenting as a cranial polyneuropathy. Acta Otorhinolaryngol Belg. 2002; 56:319-23.

3. Steiner I, Kennedy PG. Herpes simplex virus latent infection in the nervous system. J Neurovirol. 1995;1(1):19-29. https://doi.org/10.1136/ jnnp.71.2.149

4. Kim YH, Chang MY, Jung HH, Park YS, Lee SH, Lee JH, et al. Prognosis of Ramsay Hunt syndrome presenting as cranial polyneuropathy. Laryngoscope. 2010;120:2270-6. https://doi.org/10.1002/lary.21108

5. A Simon Carney, Herpes Zoster Oticus, ScottBrown's Otorhinolaryngology, Head and Neck Surgery, Hodder Arnold, 7th edition, 2008, 3379-82. https://doi.org/10.1201/b15118-275

6. Patil V, Borkar M, Saoji N. Rare case report of multiple cranial nerve involvement in Ramsay Hunt syndrome. Egyptian Dermatology Online Journal. 2014 Jun 1;10(1). https://doi.org/10.17511/ ijmrr.2016.i08.24 